\title{
Microcystin-Producing Genotypes from Cyanobacteria in Brazilian Reservoirs
}

\author{
Maria do Carmo Bittencourt-Oliveira, ${ }^{1,2}$ Viviane Piccin-Santos, ${ }^{1,2}$ \\ Selma Gouvêa-Barros ${ }^{1,2}$ \\ ${ }^{1}$ Departamento de Ciências Biológicas, ESALQ, Universidade de São Paulo, \\ Av. Pádua Dias 11, 13418-900, Piracicaba, São Paulo, Brasil \\ ${ }^{2}$ Pós-Graduação em Ciências Biológicas, Universidade Estadual Paulista "Júlio de Mesquita \\ Filho", Rio Claro, São Paulo, Brasil
}

Received 21 May 2010; revised 11 August 2010; accepted 15 August 2010

ABSTRACT: The aim of this study was to evaluate the use of new oligonucleotide primers (mcyB-F/R, mcyB-F/R-A, and mcyB-F/R-B) designed from Brazilian cyanobacteria for the detection of microcystinproducing genotypes in 27 environmental samples from water reservoirs and 11 strains of Microcystis. Microcystins were found using HPLC in all 11 strains and 19 of the environmental samples. The new oligonucleotide primers amplified fragments of microcystin-producing genes, including the eight environmental samples in which no microcystins were detected by HPLC, but which presented amplified fragments, thereby demonstrating the existence of microcystin-producing genes. The new oligonucleotide primers exhibited better specificity when used with environmental samples and were more reliable in comparison with those described in the literature (mcyB-FAA/RAA and mcyA-Cd/FR), which generate false-negative results. The better performance of these new oligonucleotide primers underline the need for designing molecular markers that are well fitted to the regional biological diversity. As this is a fast predictive technique for determining the presence or absence of microcystins, it could be used either alone or in conjunction with other techniques, such as the screening of samples to be sent for quantitative toxicological analysis using HPLC, thereby reducing monitoring cost and time. (C) 2010 Wiley Periodicals, Inc. Environ Toxicol 00: 000-000, 2010.

Keywords: bloom; mcyB; genetic diversity; molecular markers; whole-cell PCR; toxin

\section{INTRODUCTION}

Cyanobacterial blooms are increasingly more frequent in freshwater ecosystems in Brazil, leading to harm with

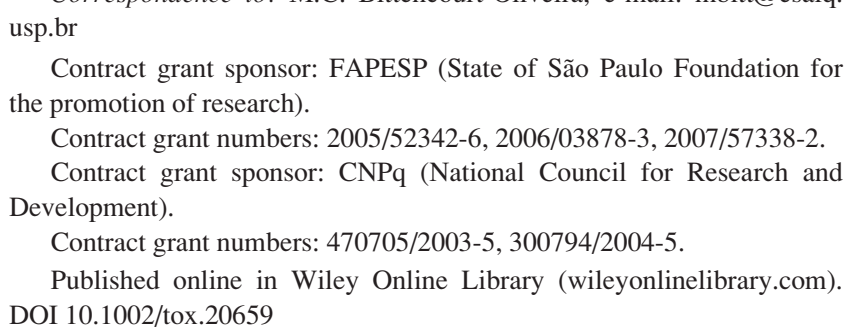
usp.br

Contract grant sponsor: FAPESP (State of São Paulo Foundation for the promotion of research).

Contract grant numbers: 2005/52342-6, 2006/03878-3, 2007/57338-2.

Contract grant sponsor: CNPq (National Council for Research and Development).

Contract grant numbers: 470705/2003-5, 300794/2004-5.

Published online in Wiley Online Library (wileyonlinelibrary.com). DOI 10.1002/tox.20659

Correspondence to: M.C. Bittencourt-Oliveira; e-mail: mbitt@esalq. regard to both public health and the environment. The worst case involving human populations took place in the city of Caruaru, Brazil. During this outbreak, patients were exposed to microcystins in the water supplying a dialysis clinic in February 1996 (Jochimsen et al., 1998). Following this occurrence, the monitoring of cyanobacteria and their toxins (microcystins) in reservoirs destined for the public water supply has become mandatory in Brazil (Regulation MS N. 518/2004).

The hepatotoxin microcystin is produced by a nonribosomal pathway through a polyketide synthase/nonribosomal peptide synthetase (PKS/NRPS) complex known as microcystin synthetase, which is responsible for the incorporation of amino acids in the peptide chain (Kleinkauf and von 
Döhren, 1996). The mcy gene cluster is responsible for toxin production, coding for microcystin synthetase (Dittmann et al., 1997; Tillett et al., 2000). Among toxinproducing cyanobacteria in Brazil, the genus Microcystis stands out and produces a number of microcystin variants (Anjos et al., 2006). Some strains of Microcystis are unable to produce toxins, but all strains with genes associated to microcystin biosynthesis should be viewed as potential toxin producers (Ouellette et al., 2006). Moreover, there are no morphological differences between toxic and nontoxic colonies. Thus, the early detection of toxic cyanobacteria in water resources is advisable in order to avoid contamination and public health problems.

Agreement among analyses by enzyme-linked immunosorbent assays (ELISA), high performance liquid chromatography (HPLC), and molecular markers has confirmed the applicability of detection by polymerase chain reaction (PCR) of potentially toxic cyanobacterial populations (Kurmayer et al., 2002; Bittencourt-Oliveira, 2003; Hisbergues et al., 2003; Mankiewicz-Boczec et al., 2006; Saker et al., 2007; Dyble et al., 2008). In a previous study, BittencourtOliveira (2003) investigated the presence of the $m c y \mathrm{~B}$ gene in 60 Brazilian strains of Microcystis spp. isolated from 15 reservoirs used for the public water supply. In the study, 18 of all strains analyzed using the oligonucleotide primers FAA/RAA (Neilan et al., 1999) exhibited amplification for the $m c y \mathrm{~B}$ gene and confirmation of microcystin production was obtained by ELISA.

In pilot experiments with environmental samples containing microcystin-producing cyanobacteria, the primers FAA/RAA and mcyA-Cd/FR (Hisbergues et al., 2003) generated false negative results (data not shown). This led to the need for constructing new primers that are suitable to the diversity of the community of cyanobacteria in aquatic systems in Brazil. Mcy gene clusters are different with respect to organization and nucleotide sequences (Mikalsen et al., 2003, Tooming-Klunderud et al., 2008). The consequence of these genetic variations is not yet fully understood (Hotto et al., 2007).

It is our hypothesis that oligonucleotide primers designed from non-Brazilian strains would not be efficient enough in detecting microcystin-producing genotypes or even exploring the genetic diversity of Microcystis populations and would therefore underestimate their toxic potential. This is supported by the following facts: (a) a number of species of cyanobacteria are not cosmopolitan; (b) there is considerable genetic variability among the different geographic locations; and (c) Brazil has one of the greatest biodiversities on earth.

The aim of this study was to evaluate three sets of new oligonucleotide primers designed from Brazilian cyanobacteria for the detection of microcystin genes in cultivated strains and environmental samples from different water reservoirs. As culture-independent molecular methods used in the monitoring of aquatic ecosystems are necessary, a fur- ther aim was to use environmental samples without DNA extraction (Pan et al., 2002) and the results were compared with those obtained with DNA extraction.

\section{MATERIALS AND METHODS}

\section{Sampling and Strains of Cyanobacteria}

Eleven clonal and nonaxenic strains of Microcystis spp. and 27 environmental samples were used. Strains were isolated from aquatic habitats in different geographic regions of Brazil. Environmental samples were collected from reservoirs used for the public water supply, using a plankton net with $25 \mu \mathrm{m}$ mesh and/or van Dorn bottle (Tables I and II).

All cultures belong to the Brazilian Cyanobacteria Collection of the University of São Paulo (BCCUSP; previously named FCLA), Brazil. The unialgal strains NPJB-1, NPLJ-4, and NPLJ-47 were obtained from the Cyanobacteria Collection of the Instituto Carlos Chagas-Universidade Federal do Rio de Janeiro.

Morphological identification of cyanobacteria was performed based on Geitler (1932) and Komárek and Anagnostidis $(1998,2005)$.

\section{Sample Treatment}

DNA was extracted from the environmental samples, from isolated strains in the exponential growth phase and from lyophilized material (Billings reservoir, May 2004). For the environmental samples, PCR amplification was performed on genomic DNA obtained from an extraction process and whole-cells (whole-cell PCR).

One milliliter from the environmental sample was centrifuged and used to extract DNA. DNA extraction was performed using cetyltrimethyl ammonium bromide (CTAB) buffer $(2 \% \mathrm{w} / \mathrm{v})$ incubated at $60^{\circ} \mathrm{C}$ in a water bath for $30 \mathrm{~min}$ (Roger and Bendich, 1985). Sixty microliter of chloroform:isoamyl alcohol (24:1 v/v) was added, mixed by gentle inversion and centrifuged (14,000 rpm for $5 \mathrm{~min}$ at $25^{\circ} \mathrm{C}$ ). The supernatant was transferred to a sterile microcentrifuge tube and digested with RNAse $(10 \mathrm{mg} / \mu \mathrm{L})$ at $37^{\circ} \mathrm{C}$ for $15 \mathrm{~min}$. The DNA was precipitated with isopropanol, followed by elution in TE buffer.

The whole-cell PCR used $\sim 1 \mathrm{~mL}$ of environmental samples containing plenty of Microcystis colonies. These colonies were directly collected from sample with an automatic pipette and washed three times by centrifugation $(14,000$ rpm for $5 \mathrm{~min}$ ) with distilled water to remove PCR-inhibiting substances. The supernatant was carefully removed and the cells were warmed in a bath at $50^{\circ} \mathrm{C}$ for $30 \mathrm{~min}$. An aliquot of $4 \mu \mathrm{L}\left(\sim 10^{4}\right.$ cells $)$ was used for the PCR. 
TABLE I. Microcystis strains used in this study

\begin{tabular}{lccc}
\hline Strains & Locality & Sample Date & Morphospecies $^{\mathrm{a}}$ \\
\hline BCCUSP 100 & Barra Bonita Reservoir, SP & April 2000 & M. panniformis Komárek et al. \\
BCCUSP 155 & Garças lagoon, SP & December 1996 & M. aeruginosa (Kützing) Kützing \\
BCCUSP 232 & Garças lagoon, SP & March 1997 & M. aeruginosa (Kützing) Kützing \\
BCCUSP 235 & Gaças lagoon, SP & April 1997 & M. aeruginosa (Kützing) Kützing \\
BCCUSP 255 & Garças lagoon, SP & December 1996 & M. aeruginosa (Kützing) Kützing \\
BCCUSP 262 & Garças lagoon, SP & March 1997 & M. aeruginosa (Kützing) Kützing \\
BCCUSP 298 & Gaças lagoon, SP & May 1997 & Meruginosa (Kützing) Kützing \\
BCCUSP 299 & Garças lagoon, SP & February 1997 & M. aeruginosa (Kützing) Kützing \\
NPJB1 & Garças lagoon, SP & 1990 & M. aeruginosa (Kützing) Kützing \\
NPLJ4 & Jacarepaguá lagoon, RJ & 1995 & Microcystis sp. \\
NPLJ47 & Jacarepaguá lagoon, RJ & 1996 & Microcystis sp.
\end{tabular}

Barra Bonita Reservoir, SP (22 $32^{\prime} 34.5^{\prime \prime} \mathrm{S}$ and $\left.48^{\circ} 29^{\prime} 26.4^{\prime \prime} \mathrm{W}\right)$. Garças lagoon, SP ( $23^{\circ} 39^{\prime} \mathrm{S}$ and $\left.46^{\circ} 37^{\prime} \mathrm{W}\right)$. Jacarepaguá lagoon, RJ (22 $54^{\prime} 10^{\prime \prime} \mathrm{S}$ and $43^{\circ} 12^{\prime} 27^{\prime \prime}$ W). BCCUSP, Brazilian Cyanobacteria Collection of University of São Paulo; NP, Cyanobacteria Collection of the Instituto Carlos Chagas Universidade Federal do Rio de Janeiro; RJ, Rio de Janeiro state; SP, São Paulo state.

${ }^{a}$ Species designations are as determined by morphology.

TABLE II. Environmental samples from Brazil used in this study

\begin{tabular}{|c|c|c|c|c|}
\hline Code & Locality & Coordinates & Sample Date & More Frequent Morphospecies ${ }^{\mathrm{a}, \mathrm{b}}$ \\
\hline BI. $1^{\mathrm{c}}$ & Billings-SP & $23^{\circ} 50^{\prime} 41^{\prime \prime} \mathrm{S}, 46^{\circ} 39^{\prime} 25^{\prime \prime} \mathrm{W}$ & $05 / 2004$ & M. nov., M.pan., M. aer. \\
\hline BI.2 & Billings-SP & $23^{\circ} 50^{\prime} 41^{\prime \prime} \mathrm{S}, 46^{\circ} 39^{\prime} 25^{\prime \prime} \mathrm{W}$ & $02 / 17 / 2006$ & M.nov., M. aer., M.pan. \\
\hline BI.3 & Billings-SP & $23^{\circ} 50^{\prime} 41^{\prime \prime} \mathrm{S}, 46^{\circ} 39^{\prime} 25^{\prime \prime} \mathrm{W}$ & $10 / 06 / 2005$ & M. nov., M. aer. M. pan., M.wes. \\
\hline BI.4 & Billings-SP & $23^{\circ} 50^{\prime} 41^{\prime \prime} \mathrm{S}, 46^{\circ} 39^{\prime} 25^{\prime \prime} \mathrm{W}$ & $05 / 19 / 2005$ & M.nov., M.pan., M. aer. \\
\hline BI.5 & Billings-SP & $23^{\circ} 43^{\prime} \mathrm{S}, 46^{\circ} 35^{\prime} \mathrm{W}$ & 02/06/2007 & C.rac.-S, M.pan., M. nov. \\
\hline BI.6 & Billings-SP & $23^{\circ} 43^{\prime} \mathrm{S}, 46^{\circ} 35^{\prime} \mathrm{W}$ & $02 / 13 / 2007$ & C.rac.-S, M.pan., M. nov. \\
\hline BI.7 & Billings-SP & $23^{\circ} 43^{\prime} \mathrm{S}, 46^{\circ} 35^{\prime} \mathrm{W}$ & $02 / 28 / 2007$ & C.rac.-S, M.pan., M. nov. \\
\hline BI.8 & Billings-SP & $23^{\circ} 43^{\prime} \mathrm{S}, 46^{\circ} 35^{\prime} \mathrm{W}$ & 03/06/2007 & M. pan., M. nov., C. rac.-S \\
\hline BI.9 & Billings-SP & $23^{\circ} 43^{\prime} \mathrm{S}, 46^{\circ} 35^{\prime} \mathrm{W}$ & 03/14/2007 & M.pan., M. nov. \\
\hline CP.1 & Carpina-PE & $07^{\circ} 54^{\prime} 15^{\prime \prime} \mathrm{S}, 35^{\circ} 20^{\prime} 27^{\prime \prime} \mathrm{W}$ & $02 / 13 / 2006$ & M.pan., C.rac.-S, C.rac.-C., G.amp. \\
\hline CP.2 & Carpina-PE & $07^{\circ} 54^{\prime} 15^{\prime \prime} \mathrm{S}, 35^{\circ} 20^{\prime} 27^{\prime \prime} \mathrm{W}$ & $09 / 18 / 2006$ & M.pan., C.rac.-S, C.rac.-C \\
\hline CP.3 & Carpina-PE & $07^{\circ} 53^{\prime} 51^{\prime \prime} \mathrm{S}, 35^{\circ} 20^{\prime} 13^{\prime \prime} \mathrm{W}$ & $06 / 30 / 2008$ & M.pan., C.rac.-S, C.rac.-C, M.nov. \\
\hline CP.4 & Carpina-PE & $07^{\circ} 53^{\prime} 51^{\prime \prime} \mathrm{S}, 35^{\circ} 20^{\prime} 13^{\prime \prime} \mathrm{W}$ & $07 / 21 / 2008$ & M. pan., C. rac.-S, C. rac.-C, M. nov., M. bot. \\
\hline CP.5 & Carpina-PE & $07^{\circ} 53^{\prime} 51^{\prime \prime} \mathrm{S}, 35^{\circ} 20^{\prime} 13^{\prime \prime} \mathrm{W}$ & $07 / 28 / 2008$ & M.pan., C.rac.-S, C.rac.-C \\
\hline СР.6 & Carpina-PE & $07^{\circ} 53^{\prime} 51^{\prime \prime} \mathrm{S}, 35^{\circ} 20^{\prime} 13^{\prime \prime} \mathrm{W}$ & 08/04/2008 & M.pan., C.rac.-S, C.rac.-C \\
\hline MU.1 & Mundaú-PE & $08^{\circ} 56^{\prime} 77^{\prime \prime} \mathrm{S}, 36^{\circ} 29^{\prime} 55^{\prime \prime} \mathrm{W}$ & $09 / 19 / 2006$ & M. pan., C.rac.-S, C.rac.-C, M. nov. \\
\hline MU.2 & Mundaú-PE & $08^{\circ} 57^{\prime} 17^{\prime \prime} \mathrm{S}, 36^{\circ} 29^{\prime} 55^{\prime \prime} \mathrm{W}$ & $04 / 14 / 2008$ & C.rac.-C, C.rac.-S, M. nov., M.pan. \\
\hline TAQ & Taquacetuba-SP & $23^{\circ} 50^{\prime} 41^{\prime \prime} \mathrm{S}, 46^{\circ} 39^{\prime} 25^{\prime \prime} \mathrm{W}$ & $02 / 16 / 2007$ & M.pan., M.aer. \\
\hline JU.1 & Jundiaí-SP & $23^{\circ} 37^{\prime} 44.50^{\prime \prime} \mathrm{S}, 46^{\circ} 11^{\prime} 50.29^{\prime \prime} \mathrm{W}$ & 02/07/2007 & Anabaena spp. \\
\hline JU.2 & Jundiaí-SP & $23^{\circ} 37^{\prime} 44.50^{\prime \prime} \mathrm{S}, 46^{\circ} 11^{\prime} 50.29^{\prime \prime} \mathrm{W}$ & $02 / 14 / 2007$ & Anabaena spp. \\
\hline JU.3 & Jundiaí-SP & $23^{\circ} 37^{\prime} 44.50^{\prime \prime} \mathrm{S}, 46^{\circ} 11^{\prime} 50.29^{\prime \prime} \mathrm{W}$ & 03/01/2007 & Anabaena spp. \\
\hline JU.4 & Jundiaí-SP & $23^{\circ} 37^{\prime} 20.01^{\prime \prime} \mathrm{S}, 46^{\circ} 10^{\prime} 38.99^{\prime \prime} \mathrm{W}$ & 02/07/2007 & Anabaena spp. \\
\hline JU.5 & Jundiaí-SP & $23^{\circ} 37^{\prime} 20.01^{\prime \prime} \mathrm{S}, 46^{\circ} 10^{\prime} 38.99^{\prime \prime} \mathrm{W}$ & $02 / 14 / 2007$ & Anabaena spp. \\
\hline JU.6 & Jundiaí-SP & $23^{\circ} 38^{\prime} 58.60^{\prime \prime} \mathrm{S}, 46^{\circ} 11^{\prime} 35.30^{\prime \prime} \mathrm{W}$ & 02/07/2007 & Anabaena spp. \\
\hline JU.7 & Jundiaí-SP & $23^{\circ} 38^{\prime} 58.60^{\prime \prime} \mathrm{S}, 46^{\circ} 11^{\prime} 35.30^{\prime \prime} \mathrm{W}$ & $02 / 14 / 2007$ & Anabaena spp. \\
\hline RG & Rio Grande-SP & $23^{\circ} 46^{\prime} 09 \mathrm{~S}, 46^{\circ} 31^{\prime} \mathrm{W}$ & $03 / 27 / 2008$ & $\begin{array}{c}\text { A. cir., Anabaena spp., C. rac.-S, } \\
\text { M. nov., M. pan., M. prot. }\end{array}$ \\
\hline $\mathrm{PC}$ & Paiva Castro-SP & $23^{\circ} 20^{\prime} 13.60^{\prime \prime} \mathrm{S}, 46^{\circ} 39^{\prime} 40.00^{\prime \prime} \mathrm{W}$ & 03/06/2007 & E.bras. \\
\hline
\end{tabular}

PE, Pernambuco state; SP, São Paulo state; A. circ., Anabaena circinalis Rabenhorst; C. rac.-S, Cylindrospermopsis raciborskii (Wolosz.) Seenayya \& Subba Raju straight morphotype; C. rac.-C, C. raciborskii coiled morphotype; E. bras., Epigloeosphaera brasilica Azevedo et al.; G.amp., Geitlerinema amphibium (Ag. ex Gom.) Anagnostidis; M. aer., M. aeruginosa (Kützing) Kützing; M. bot., M. botrys Teiling; M. nov., M. novacekii (Komárek) Compére; M. pan., M. panniformis Komárek et al.; M. prot., M. protocystis Crow; M. wes., M. wesenbergii (Komárek) Komárek.

${ }^{a}$ Species designations are as determined by morphology.

${ }^{\mathrm{b}}$ Decreasing frequency ordination.

${ }^{c}$ Lyophilized sample. 
TABLE III. Oligonucleotide primers used for identification of genes cpcBA (phycocyanin), mcyA (microcystin synthetase A), and mcyB (microcystin synthetase B)

\begin{tabular}{|c|c|c|c|}
\hline Set primers & Sequence $\left(5^{\prime}\right.$ to $\left.3^{\prime}\right)$ & Source & Fragment \\
\hline \multicolumn{4}{|l|}{$c p c \mathrm{BA}$} \\
\hline $\mathrm{PC} \beta-\mathrm{F}$ & GGCTGCTTGTTTACGCGACA & Neilan et al. 1995 & 685 \\
\hline $\mathrm{PC} \alpha-\mathrm{R}$ & CCAGTACCACCAGCAACTAA & & \\
\hline \multicolumn{4}{|c|}{$\mathrm{cos}$} \\
\hline$m c y \mathrm{~A}-\mathrm{Cd} / \mathrm{F}$ & AAAATTAAAAGCCGTATCAAA & Hisbergues et al. 2003 & 297 \\
\hline$m c y \mathrm{~A}-\mathrm{Cd} / \mathrm{R}$ & AAAAGTGTTTTATTAGCGGCTCAT & & \\
\hline \multicolumn{4}{|c|}{ 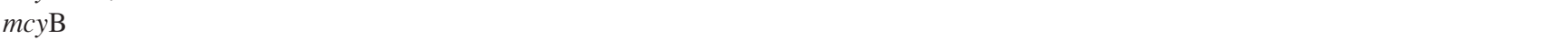 } \\
\hline FAA & CTATGTTATTTATACATCAGG & Neilan et al. 1999 & 785 \\
\hline RAA & CTCAGCTTAACTTGATTATC & & \\
\hline \multicolumn{4}{|c|}{ (1) } \\
\hline$m c y \mathrm{~B}-\mathrm{F}$ & TTCAACGGGAAAACCCAAAG & This study & \\
\hline$m c y \mathrm{~B}-\mathrm{R}$ & CYAATATGTAAYTCTCCAG & This study & 570 \\
\hline$m c y \mathrm{~B}-\mathrm{R}-\mathrm{A}$ & GGCTATATTTTCATCCCATT & This study & 315 \\
\hline$m c y \mathrm{~B}-\mathrm{R}-\mathrm{B}$ & GTCAGGTTTAGCCACGACT & This study & 195 \\
\hline
\end{tabular}

\section{Oligonucleotide Primers Design}

Primer 3 version 4.0 (Rozen and Skaletsky, 2000) was used to design the three pairs of oligonucleotide primers. The choice of the primer sequences was made based on the oligonucleotide primer options generated by the software program, such as Tm parameters, \%GC, dimerization, hairpin formation, and extremity stability.

Three new oligonucleotide primers $(m c y \mathrm{~B}-\mathrm{F} / \mathrm{R}, m c y \mathrm{~B}-\mathrm{F} /$ $\mathrm{R}-\mathrm{A}$, and $m c y \mathrm{~B}-\mathrm{F} / \mathrm{R}-\mathrm{B}$ ) were designed based on the sequencing of $m c y \mathrm{~B}$ fragments amplified with FAA/RAA (Neilan et al., 1999) with 759 to 822 bp using 15 Brazilian Microcystis strains (Bittencourt-Oliveira et al., 2011) and several others available in the GenBank and EMBL databases. All were microcystin-producing strains.

The selected primer sequences were checked for homology with other known sequences deposited in the databases using the Basic Local Alignment Search Tool (BLAST) (Altschul et al., 1997). Some strains of Anabaena and Planktothrix as well as many strains of Microcystis, which is the genus responsible for the majority of cyanobacterial blooms in Brazil, demonstrated homology.

\section{PCR Amplification}

The polymerase chain reaction (PCR) was performed in a GeneAmp PCR System 9700 thermocycler (Applied Biosystems, Foster City, CA), using the specific pureTaq Ready-To-Go PCR Beads (Amersham, Piscataway, NJ), with $20 \mu \mathrm{M}$ of each oligonucleotide primer in a total volume of $25 \mu \mathrm{L}$.

For PCR amplification of three new oligonucleotide primers pairs $(m c y \mathrm{~B}-\mathrm{F} / \mathrm{R}, m c y \mathrm{~B}-\mathrm{F} / \mathrm{R}-\mathrm{A}$, and $m c y \mathrm{~B}-\mathrm{F} / \mathrm{R}-\mathrm{B})$, the following sequence of cycling parameters was used: $94^{\circ} \mathrm{C}$ for $2 \mathrm{~min}, 35$ cycles at $94^{\circ} \mathrm{C}$ for $10 \mathrm{~s} ; 50^{\circ} \mathrm{C}$ for $20 \mathrm{~s}$, and $72^{\circ} \mathrm{C}$ for $1 \mathrm{~min}$, followed by final extension at $72^{\circ} \mathrm{C}$ for 5 min. For the oligonucleotide primers FAA/RAA (mcyB) and $m c y \mathrm{~A}-\mathrm{Cd} / \mathrm{FR}(m c y \mathrm{~A})$, the amplification reactions were carried out using the conditions described by Neilan et al. (1999) and Hisbergues et al. (2003), respectively.

Oligonucleotide primers for the phycocyanin operon ( $c p c$ BA) (Neilan et al., 1995) were used to confirm the presence of cyanobacterial DNA in samples, based on the procedure described by Baker et al. ( 2001). DNA from microcystin-producing strains, as BCCUSP155, 232, 298, or 299, was used as positive control at the same reaction conditions with the same primers (data not shown). Negative controls were carried out by using the same reaction conditions and primers, but without template DNA. All primers were synthesized by IDT (Medley, FL).

PCR reactions were performed at least in duplicate. The oligonucleotide primers used are listed in Table III.

Amplification products were visualized on electrophoresis on $0.7 \%$ agarose gels stained with ethidium bromide $(0.2 \mu \mathrm{g} / \mathrm{mL})$ in $1 \times \mathrm{TBE}$ running buffer and recorded using the Electrophoresis Documentation and Analysis System 290 (EDAS 290) (Kodak, Melville, NY).

\section{Sequencing}

The amplified fragments from the environmental samples from the Carpina and Mundaú reservoirs ( $m c y \mathrm{~B}-\mathrm{F} / \mathrm{R}$ Number Accession $\mathrm{x}=\mathrm{HQ}$ 232485; mcyB-F/R-A Number Accession $\mathrm{y}=232487$; $m c y \mathrm{~B}-\mathrm{F} / \mathrm{R}-\mathrm{B}$ Number Accession $\mathrm{z}=\mathrm{HQ}$ 232486; $m c y \mathrm{~A}-\mathrm{Cd} / \mathrm{FR}$ Number Accession $\mathrm{w}=\mathrm{HQ}$ 232484) were directly sequenced using the forward and reverse primers with the DYEnamic ET Terminator Cycle Sequencing Kit (Amersham Biosciences, Pittsburgh, PA) in the 3100 ABI Sequencher (Applied Biosystems, Foster City, CA), following the manufacturer's instructions. To avoid PCR-generated errors, at least two separate amplification reactions were pooled for sequencing. The PCR 
products were sequenced on both strands. The sequences were initially analyzed by a similarity search using BLAST (Altschul et al., 1997) to determine the identity to homologue sequences.

\section{Microcystin Analysis}

Microcystin production was determined via immunoassay using the ELISA EnviroLogix ${ }^{\mathrm{TM}}$ Microcystin Plate Kit (EnviroLogix Inc, Maine), based on the procedure described by Chu et al. (1989), as well as with HPLC-UV, based on the procedure described by Lawton et al. (1994). HPLC analyses were performed with a Shimadzu HPLC System equipped with a Shimadzu UV-SPD $10 \mathrm{~A}_{\mathrm{VP}}$ detector at $238 \mathrm{~nm}$.

\section{RESULTS}

\section{Cultured Strains}

Microcystins were detected by HPLC or ELISA in all the strains studied (Table IV). The three pairs of designed oligonucleotide primers $(m c y \mathrm{~B}-\mathrm{F} / \mathrm{R}, m c y \mathrm{~B}-\mathrm{F} / \mathrm{R}-\mathrm{A}$, and $m c y \mathrm{~B}-$ $\mathrm{F} / \mathrm{R}-\mathrm{B}$ ) gave rise to amplified fragments of expected sizes in all strains exhibiting microcystin production by HPLC.

Ten of eleven strains examined were compatible with microcystin production when analyzed by HPLC. Results for the sole strain BCCUSP255 revealed that microcystin was absent when analyzed with HPLC, but present when the ELISA method was used. Such results could either be a false-positive in the detection by ELISA or signify that the microcystin was below the resolution limit of the HPLC method. Since the microcystin concentration obtained from the NPLJ-4 strain was $0.013 \mathrm{ng} / \mathrm{mg}$, therefore, 10 times smaller than the one from BCCUSP255, we come thus to the conclusion that the result from ELISA was false-positive. Also for the BCCUSP255 strain, the oligonucleotide primers FAA/RAA provided a positive result for the presence of the gene involved in microcystin biosynthesis, although all other primer sets provided negative results. As four of the five molecular markers confirmed the HPLC result (absence of microcystin), we came to the conclusion that the FAA/RAA presented a false-positive. The other variation occurred with the BCCUSP100 strain, which produced microcystin and presented a single negative result for $m c y \mathrm{~A}-\mathrm{Cd} / \mathrm{FR}$.

\section{Environmental Samples}

The sequences obtained using the three new oligonucleotide primers exhibited high similarity with species of Microcystis as well as other noncultured, unidentified cyanobacteria. The sequence generated by $m c y \mathrm{~B}-\mathrm{F} / \mathrm{R}$ (accession number $X=$ HQ 232485) exhibited $98 \%$ identity with six sequences from $M$. aeruginosa (AB474608.1, AB474602.1, AB474593.1, EU009867.1, AB019578.2, and AJ492553.1). Regarding the oligonucleotide primer mcyB$\mathrm{F} / \mathrm{R}-\mathrm{B}$, the sequence with accession number $Z=\mathrm{HQ}$ 232486 exhibited $98 \%$ similarity to $M$. aeruginosa (AP009552.1) and $M$. viridis (EF115401.1). Accession number $Y=$ HQ 232487 from $m c y$ B-F/R-A exhibited 99\% identity with $M$. aeruginosa (EU009869.1, EU009866.1, and AJ492552.1).

Potentially hepatotoxic cyanobacteria were frequently present in all samples analyzed. Species from the genus Microcystis were the most recurrent, particularly $M$. novacekii, M. panniformis, and M. aeruginosa (Table II). All samples from the Billings, Rio Grande, Taquacetuba, Carpina, and Mundaú reservoirs were blooming with scum formed mostly by Microcystis spp. In the Jundiai reservoir, species from the genus Anabaena were predominant, with straight and coiled trichomes, which were not identified because of missing akinetes and rare occurrences of heterocytes. Microcystis colonies were found in the same reservoir, but in small quantities. The sample from the Paiva Castro reservoir, although not visually exhibiting a bloom, had several colonies of chroococcacean picoplankton Epigloeosphaera brasilica Azevedo et al. (Fig. 1), which produced substantial quantities of microcystins $(2.35 \mu \mathrm{g} / \mathrm{L})$.

Cyanobacteria were confirmed by the amplification of $c p c \mathrm{BA}$ in all samples. For the RG sample (Table V), the amplification of two bands was observed with these primers, likely because of the presence of other genera of cyanobacteria with different sizes for this fragment, such as Anabaena and Microcystis.

From the total of 27 environmental samples containing cyanobacteria, microcystins were found in 21 using HPLC where in six from these the concentration was not measured but their presence was detected. In all these 21 samples, the new oligonucleotide primers $(m c y \mathrm{~B}-\mathrm{F} / \mathrm{R}, m c y \mathrm{~B}-\mathrm{F} / \mathrm{R}-\mathrm{A}$, and $m c y \mathrm{~B}-\mathrm{F} / \mathrm{R}-\mathrm{B}$ ) amplified fragments in at least one of the treatments (DNA extraction and/or whole-cell PCR), indicating microcystin-producing genotypes (Table V). An example of agarose gel is shown in Figure 2.

Among these 21 samples (except BI.1, which was not tested), microcystin-producing genotypes were detected in 12 samples using the mcyA-Cd/FR primer set (Table V). Among the seven samples from Jundiai with a predomination of Anabaena species (Table II), the mcyA-Cd/FR primer set was positive for six (Table V). However, for 16 samples presenting microcystins analyzed with the FAA/ RAA, only one was positive, while the remaining were false-negative.

In six samples (BI.2, CP.3, CP.4, CP.5, CP.6, and MU.1) from three reservoirs (Carpina, Mundaú, and Billings), no microcystins were found using HPLC. In two out of these samples, microcystins were found using ELISA (CP.3 and CP.6) (Table V). However, using the new oligonucleotide primers with both methodologies (DNA extraction and 


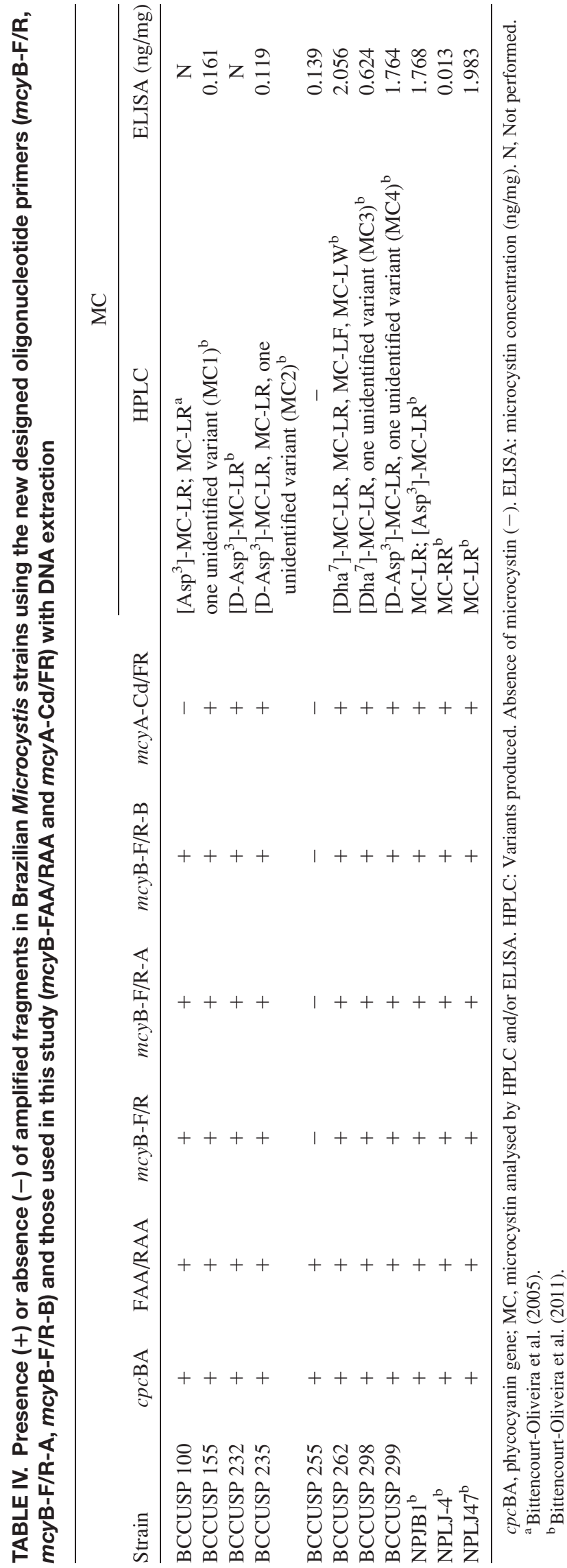

whole-cell PCR), amplified fragments were obtained, indicating the existence of microcystin synthetase genes.

Unexpected fragments (other than the specific one) occurred sparsely in the amplification reactions using the oligonucleotide primer $m c y \mathrm{~B}-\mathrm{F} / \mathrm{R}-\mathrm{A}$ pair, but without interfering in the reading of results, since these fragments were less evident. In the case of $m c y \mathrm{~B}-\mathrm{F} / \mathrm{R}-\mathrm{B}$, unexpected fragments were more frequent and in larger number, with variable intensities, sometimes confounding the correct interpretation. $M c y \mathrm{~B}-\mathrm{F} / \mathrm{R}$ only revealed the expected fragments and was $100 \%$ in agreement with the positive results for microcystin detected using HPLC. Moreover, mcyB-F/R was also positive for all samples in which microcystin was not detected by HPLC.

By comparing the PCR reactions using samples submitted to two treatments, we found out that efficiency was slightly higher with DNA extraction than whole-cell PCR. However, nonspecific fragments were more frequent in the extracted DNA.

\section{DISCUSSION}

Seven reservoirs the northeastern (state of Pernambuco) and southeastern (state of São Paulo) regions of Brazil, which are used intensively for the public water supply and leisure, were investigated for the detection of microcystinproducing genotypes using the PCR amplification of the $m c y \mathrm{~B}$ and $m c y \mathrm{~A}$ genes. To achieve this goal, three new oligonucleotide primers $(m c y \mathrm{~B}-\mathrm{F} / \mathrm{R}, m c y \mathrm{~B}-\mathrm{F} / \mathrm{R}-\mathrm{A}$, and $m c y \mathrm{~B}-$ F/R-B) based on sequences from Brazilian strains were designed. Additionally, other oligonucleotide primers (FAA/RAA and mcyA-Cd/FR) described in the literature were used for comparison, Neilan et al. (1999) and Hisbergues et al. (2003), respectively. All environmental

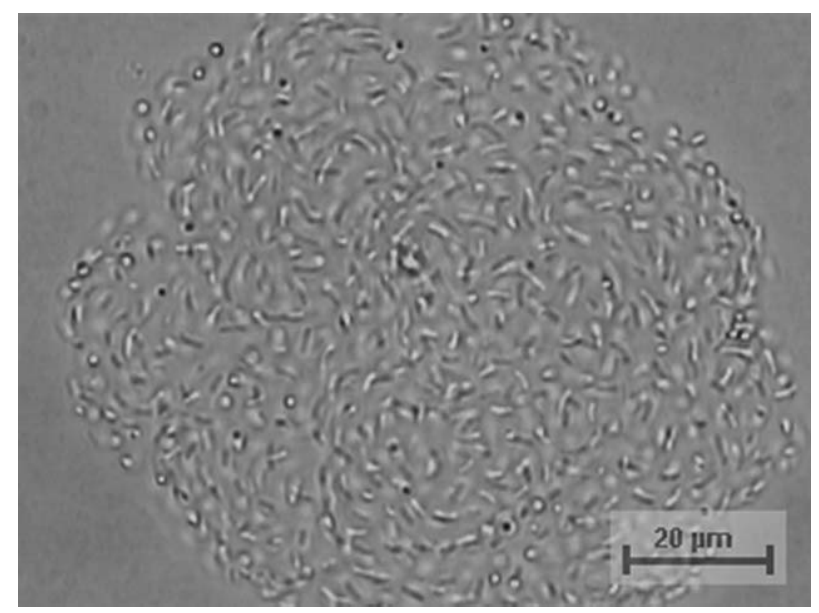

Fig. 1. Photomicrography of the colonial cyanobacterium Epigloeosphaera brasilica Azevedo et al., which blooms with the release of microcystins. 


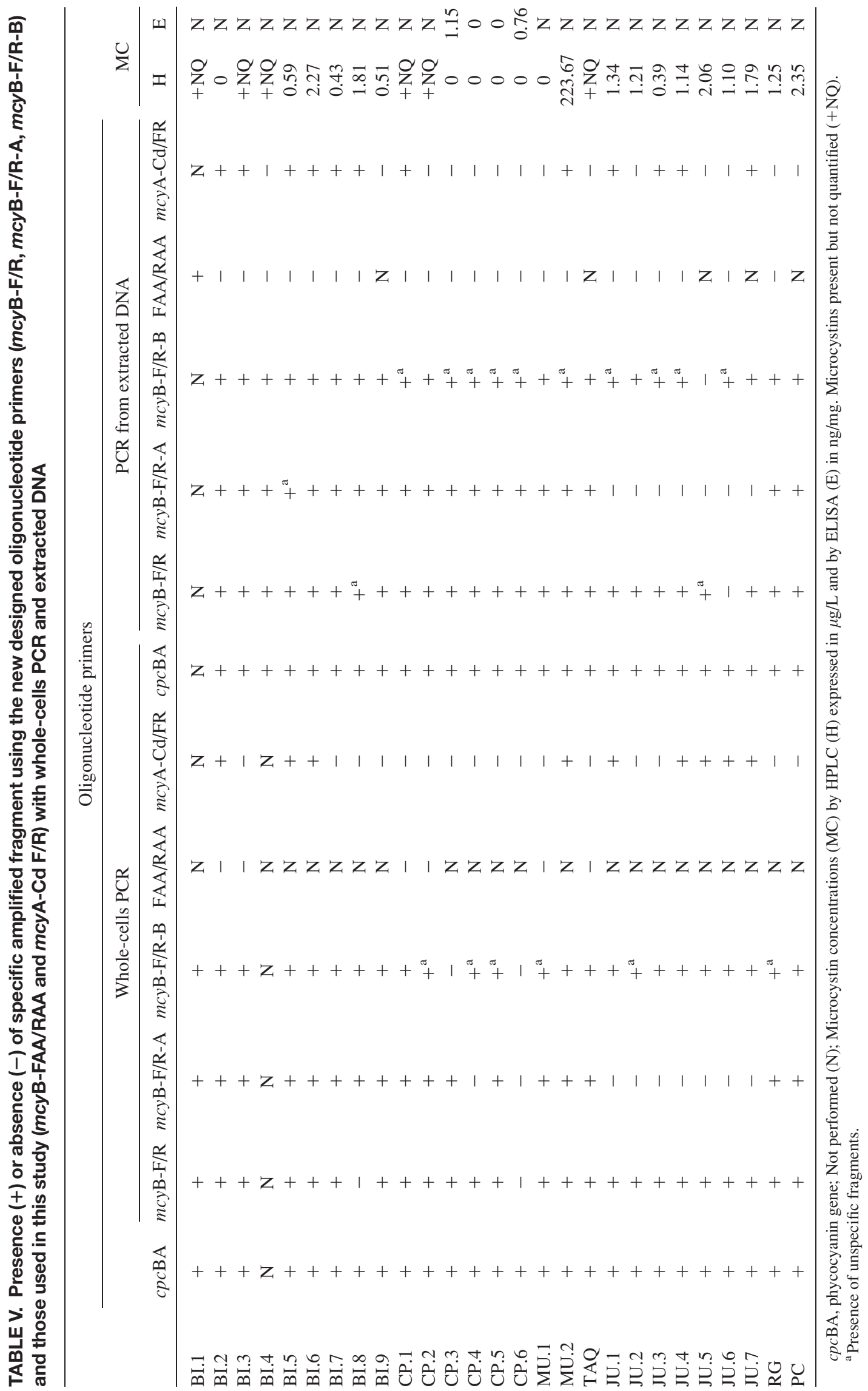




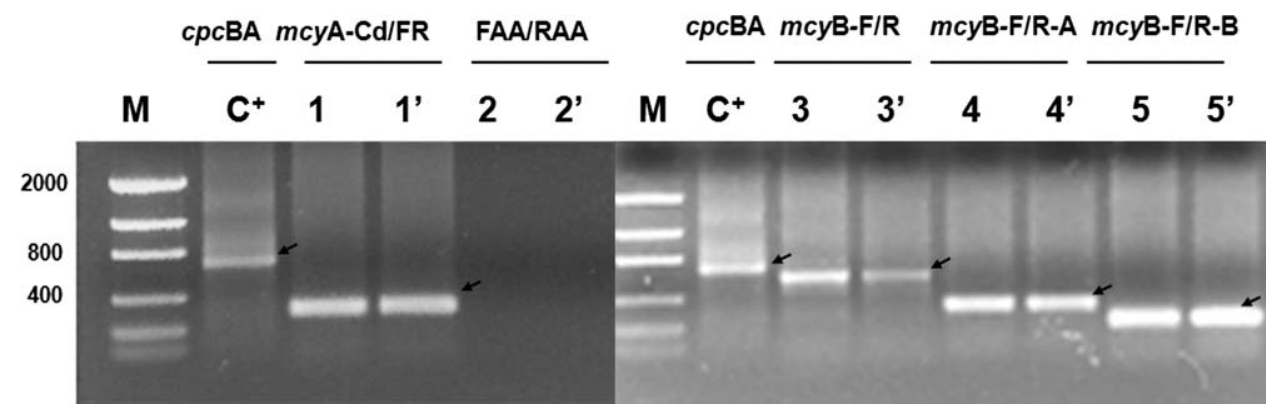

Fig. 2. Electrophoresis in agarose gel showing amplification products obtained from the oligonucleotide primers used in this study from DNA extraction (in duplicate); Billings reservoir, SP, February 17, 2006; M, Molecular marker (Low DNA Mass Ladder, base pairs); $\mathrm{C}^{+}$, Presence of DNA cyanobacterial in the sample; Specific fragment (arrow).

samples exhibited cyanobacteria with a potential for microcystin production, that is, with PCR amplification for $m c y$ genes, which were detected by one or more oligonucleotide primers.

There are frequent reports of blooms of cyanobacteria in the reservoirs sampled (Souza et al., 1998; Bouvy et al., 2000; Anjos et al., 2006; Moura et al., 2007; Dantas et al., 2008), mainly species of Microcystis. The production of microcystin in blooms of Epigloeosphaera brasilica was recorded for the first time. Picoplankton cyanobacteria are generally overlooked in the monitoring of water supplies, but their toxic potential is considerable and should be measured (Domingos et al., 1999).

The applicability of $m c y$ genes as molecular markers for microcystin detection in environmental or culture samples has been widely demonstrated (Kurmayer et al., 2002; Pan et al., 2002; Via-Ordorika et al., 2004; Mbedi et al., 2005; Oberholster et al., 2006; Rantala et al., 2006; MankiewiczBoczek et al., 2006). In this study, markers for $m c y \mathrm{~B}$ proved to be more efficient in detecting toxic genotypes than markers for mcyA.

In a study on three Polish lakes in which Microcystis aeruginosa, Planktothrix agardhii and Planktolyngbya spp. predominated, Mankiewicz-Boczek et al. (2006) found variation in the detection of toxic genotypes using oligonucleotide primers for different mcy genes. The $m c y \mathrm{E}$ gene was amplified in $100 \%$ of samples with microcystins, while $m c y \mathrm{~B}$ was amplified in $96 \%$ of samples; $m c y \mathrm{D}$ and $m c y \mathrm{~A}$ were only amplified in $84 \%$ and $80 \%$ of samples, respectively. Saker et al. (2007) found the amplification of the mcyA gene, even when the concentration of cyanobacterium cells from genera that potentially produce microcystins was very low and even when microcystins were not detected. However, Via-Ordorika et al. (2004) and Mankiewicz-Boczek et al. (2006) obtained false-negative results for this oligonucleotide primer. Mbedi et al. (2005) studied variability in $m c y$ genes from Planktothrix and found $m c y \mathrm{~A}$ to exhibit greater variation and false negative results. $M c y \mathrm{~A}$ is composed of a mosaic of conserved and variable regions. This variability could result in the nonannealing of oligonu- cleotide primers and, consequently, the nonamplification of the targets (Kurmayer et al., 2005; Mbedi et al., 2005).

The primers designed for $m c y \mathrm{~B}$ in this study were much more efficient for the Brazilian strains analyzed when compared with FAA/RAA. This improved performance could be attributed to variations in the $m c y \mathrm{~B}$ gene sequences of Brazilian cyanobacterial populations, affecting the annealing of oligonucleotide primers. Among the three new primers tested, $m c y \mathrm{~B}-\mathrm{F} / \mathrm{R}$ was the most adequate, as it presented no false negative in samples with microcystins detected with HPLC. The presence of nonspecific bands in the samples using $m c y \mathrm{~B}-\mathrm{F} /$ $\mathrm{R}-\mathrm{A}$ did not impede the correct reading of the results, because the expected size of the marker was previously known. Thus, this primer could be used in association with $m c y \mathrm{~B}-\mathrm{F} / \mathrm{R}$. However, $m c y \mathrm{~B}-\mathrm{F} / \mathrm{R}-\mathrm{B}$ did not perform well due to several nonspecific bands that hampered the correct reading of the results.

Twenty-seven samples were analyzed in this study. For two of these samples (CP.4 and CP.5), the presence of microcystins was not detected by either HPLC or ELISA. Moreover, in samples MU.1 and BI.2, microcystins were not found using HPLC, but these results were not confirmed by ELISA. Amplified fragments in samples without microcystins detected by HPLC have been reported elsewhere (Kurmayer et al., 2004; Via-Ordorika et al., 2004; Ouahid et al., 2005; Mankiewicz-Boczek et al., 2006; Saker et al., 2007). There are a number of interpretations for this, such as microcystin-producing genotypes that are not expressed (Kurmayer and Kutzenberger, 2003; Bittencourt-Oliveira, 2003) or the toxin is present, but at concentrations below the detection limit of HPLC. The presence of microcystin synthetase genes does not necessarily indicate the production of microcystins, but it does indicate the potential for their production. Moreover, it is widely known that environmental factors such as light, temperature, biological rhythm and nutrients can affect microcystin production rates (Watanabe and Oishi, 1985; Utkilen and Gjølme, 1992; Lukac and Aegerter, 1993; Bittencourt-Oliveira et al., 2005). 
Kaebernick et al. (2001) recorded a spontaneous mutant of microcystin biosynthesis that had lost its capacity for toxin production. Kurmayer et al. (2004) observed in nature that microcystin is lacking in some of Planktothrix, although these strains contain all the genes for microcystin synthetase. The authors speculate that these strains lost the ability to synthesize microcystin due to gene inactivation and that another small peptide could functionally substitute this toxin.

Recent studies have demonstrated that some strains have no capacity for toxin production because they do not have the entire mcy gene cluster. Transposon insertion events could be responsible for deletions in the cluster sequence, leading to only pieces of the sequence that may still promote fragment amplification (Christiansen et al., 2006, 2008). Likewise, natural genetic mutations could occur, leading to gene inactivation and giving rise to mutant genotypes (Mbedi et al., 2005).

Whole-cell PCR proved to be a fast, simple and inexpensive technique that does not use bovine serum albumin (Pan et al., 2002) or organic solvents, as DNA extraction is not necessary. The sporadic cases of disagreement in the results between both treatments could be related to the following: presence of inhibiting substances in the PCR reaction, which is a very common circumstance in nature samples (Tsai and Olson, 1992; Carol, 1996; Pan et al., 2002); excess of cells in the reaction (Ruangyuttikarn et al., 2004); selectivity in cell lysis; PCR bias; and inefficient DNA extraction (Ravenschlag et al., 1999). Despite the advantages of whole-cell PCR, the use of DNA extraction allows storing and performing further tests if necessary. The positive amplifications for lyophilized cells indicate that this sample preservation process was also satisfactory in the molecular detection of potentially hepatotoxic cyanobacteria, thereby constituting a good alternative for sample storage.

The oligonucleotide primers specifically designed from Brazilian populations of cyanobacteria achieved better specificity and reliability in comparison to those described in Neilan et al. (1999) (FAA/RAA) and Hisbergues et al. (2003) ( $m c y$ A-Cd/FR) when used with environmental samples. Regional differences in cyanobacteria could be underestimated when primers designed from nonlocal isolates are used. This reinforces the need for studies on microcystinproducing genotype sequencing from different regions and/ or environments.

The methodology used and the new oligonucleotide primers tested have a high potential for use in the monitoring of reservoirs used for the public water supply in Brazil. Since this is a fast, predictive method for indicating the presence or absence of microcystin genes, it could be used either alone or with other techniques, such as for the screening of samples to be sent for quantitative toxicological analysis, thereby reducing monitoring costs and time.
The findings of the present study reveal that oligonucleotide primers for the detection of microcystin-producing genotypes in environmental samples should be carefully chosen in order to avoid the underestimation of their toxic potential.

\section{REFERENCES}

Altschul SF, Madden TL, Schaffer AA, Zhang J, Zhang Z, Miller W, Lipman DJ. 1997. Gapped BLAST and PSI-BLAST: A new generation of protein database search programs. Nucl Acids Res 25:3389-3402.

Anjos FM, Bittencourt-Oliveira MC, Zajac MP, Hiller S, Christian B, Erler K, Luckas B, Pinto E. 2006. Detection of harmful cyanobacteria and their toxins by both PCR amplication and LCMS during a bloom event. Toxicon 48:239-245.

Baker JA, Neilan BA, Entsch B, McKay DB. 2001. Identification of cyanobacteria and their toxigenicity in environmental samples by rapid molecular analysis. Environ Toxicol 16:472-482.

Bittencourt-Oliveira MC. 2003. Detection of potencial microcystin-producing cyanobacteria in Brazilian reservoirs with a $m c y \mathrm{~B}$ molecular marker. Harmful Algae 2:51-60.

Bittencourt-Oliveira MC, Kujbida P, Cardozo KH, Carvalho VM, Moura AN, Colepicolo P, Pinto E. 2005. A novel rhythm of microcystin biosynthesis is described in the cyanobacterium Microcystis panniformis Komárek et al. Biochem Biophys Res Commun 326:687-694.

Bittencourt-Oliveira MC, Oliveira MC, Pinto E. 2011. Diversity of microcystin-producing genotypes in Brazilian strains of Microcystis (Cyanobacteria). Braz J Biol 71 (in press).

Bouvy MA, Falcão D, Marinho M, Pagano M, Moura AN. 2000. Occurrence of Cylindrospermopsis (Cyanobacteria) in 39 Brazilian tropical reservoirs during the 1998 drought. Aquat Microb Ecol 23:13-27.

Carol AK. 1996. Relief of amplification inhibition in PCR with bovine serum albumin or T4 gene 32 protein. Appl Environ Microbiol 62:1102-1106.

Chu FS, Huang X, Wei RD, Carmichael WW. 1989. Production and characterization of antibodies against microcystins. Appl Environ Microbiol 55:1928-1933.

Christiansen G, Kurmayer R, Liu Q, Börner T. 2006. Transposons inactivate biosynthesis of the nonribosomal peptide microcystin in naturally occurring Planktothrix spp. Appl Environ Microbiol 72:117-123.

Christiansen G, Molitor C, Philmus B, Kurmayer R. 2008. Nontoxic strains of cyanobacteria are the result of major gene deletion events induced by a transposable element. Mol Biol Evol 25:1695-1704.

Dantas EW, Moura AN, Bittencourt-Oliveira MC, Arruda-Neto JDT, Cavalcanti ADC. 2008. Temporal variation of the phytoplankton community at short sampling intervals in the Mundaú reservoir. Northeastern Brazil. Acta Bot Bras 22:970-982.

Dittmann E, Neilan BA, Erhard M, von Döhren H, Börner T. 1997. Insertional mutagenesis of a peptide synthetase gene that is responsible for hepatotoxin production in the cyanobacterium Microcystis aeruginosa PCC 7806. Mol Microbiol 26:779-787. 
Domingos P, Rubim TK, Molica RJR, Azevedo SMFO, Carmichael WW. 1999. First report of microcystin production by picoplanktonic cyanobacteria species isolated from a Brazilian Northeast water supply. Environ Toxicol Water Qual 14:31-35.

Dyble J, Fahnenstiel G, Litaker RW, Millie D, Tester P. 2008. Microcystin concentrations and genetic diversity of Microcystis in the lower Great Lakes. Environ Toxicol 23:507-516.

Geitler L. 1932. Cyanophyceae. In: Kolkwitz R, editor. Rabenhorst's Kryptogamen-Flora Von Deutschland, Österreich und der Schweiz, Vol 14. Leipzig: Akademische Verlagsgesellschaft m.b.H.

Hisbergues M, Christiansen G, Rouhiainen L, Sivonen K, Börner T. 2003. PCR-based identification of microcystin-producing genotypes of different cyanobacterial genera. Arch Microbiol 180:402-410.

Hotto AM, Satchwell MF, Boyer GL. 2007. Molecular characterization of potential microcystin-producing cyanobacteria in Lake Ontario embayments and nearshore waters. Appl Environ Microbiol 73:4570-4578.

Jochimsen EM, Carmichael WW, An J, Cardo DM, Cookson ST, Holmes CEM, Antunes MB, Melo Filho DA, Lyra DM, Barreto VS, Azevedo SM, Jarvis WR. 1998. Liver failure and death after exposure to microcystin at a hemodialysis center in Brazil. N Eng J Med 338:873-878.

Kaebernick M, Rohrlack T, Christoffersen K, Neilan BA. 2001. A spontaneous mutant of microcystin biosynthesis: Genetic characterization and effect on Daphnia. Environ Microbiol 3: 669-679.

Kleinkauf H, von Döhren H. 1996. A non-ribosomal system of peptide biosynthesis. Eur J Biochem 236:335-351.

Komárek J, Anagnostidis K. 1998. Cyanoprocaryota. I. Teil Chroococcales. In: Ettl H, Gärtner G, Heynig H, Mollenhauer D editors. Süsswasserflora von Mitteleuropa. Vol 19/1. Stuttgart: Gustav Fischer Verlag. pp 1-548.

Komárek J, Anagnostidis K. 2005. Cyanoprokaryota. II. Oscillatoriales. In: Büdel B, Krienitz L, Gärtner G, Schargerl M, editors. Süßwasserflora von Mitteleuropa. Band, Vol. 19/2. München: Elsevier. 759 p.

Kurmayer R, Kutzenberger T. 2003. Application of real-time PCR for quantification of microcystin genotypes in a population of the toxic cyanobacterium Microcystis sp. Appl Environ Microbiol 9:6723-6730.

Kurmayer R, Dittmann E, Fastner J, Chorus I. 2002. Diversity of microcystin genes within a population of the toxic cyanobacterium Microcystis spp. in Lake Wannsee (Berlin, Germany). Microb Ecol 43:107-118.

Kurmayer R, Christiansen G, Fastner J, Börner T. 2004. Abundance of active and inactive microcystin genotypes in populations of the toxic cyanobacterium Planktothrix spp. Environ Microbiol 6:831-841.

Kurmayer R, Christiansen G, Gumpenberger M, Fastner J. 2005. Genetic identification of microcystin ecotypes in toxic cyanobacteria of the genus Planktothrix. Microbiol. 151:1525-1533.

Lawton LA, Edwards C, Codd GA. 1994. Extraction and high performance liquid chromatographic method for the determination of microcystins in raw and treated waters. Analyst 199:15251530 .
Lukac M, Aegerter R. 1993. Influence of trace metals on growth and toxin production of Microcystis aeruginosa. Toxicon 31:293-305.

Mankiewicz-Boczek J, Izydorczyk K, Romanowska-Duda Z, Jurczak T, Stefaniak K, Kokocinski M. 2006. Detection and monitoring toxigenicity of cyanobacteria by application of molecular methods. Environ Toxicol 21:380-387.

Mbedi S, Welker M, Fastner J, Wiedner C. 2005. Variability of the microcystin synthetase gene cluster in the genus Planktothrix (Oscillatoriales, Cyanobacteria). FEMS Microbiol Lett 245:299-306.

Mikalsen B, Boison G, Skulberg OM. Fastner J, Davies W, Gabrielsen TM, Rudi K, Jakobsen KS. 2003. Natural variation in the microcystin synthetase operon mcyABC and impact on microcystin production in Microcystis strains. J Bacteriol 185:2774-2785.

Moura AN, Bittencourt-Oliveira MC, Dantas EW, Arruda-Neto JDT. 2007. Phytoplanktonic associations: A tool to understand dominance events in a tropical brazilian reservoir. Acta Bot Bras 21:641-648.

Neilan BA, Jacobs D, Goodman AE. 1995. Genetic diversity and phylogeny of toxic cyanobacteria determined by DNA polymorphisms within the phycocyanin locus. Appl Environ Microbiol 61:3875-3883.

Neilan BA, Dittmann E, Rouhiainen L, Bass A, Schaub V, Sivonen K, Börner T. 1999. Nonribosomal peptide synthesis and toxigenicity of cyanobacteria. J Bacteriol 181:4089-4097.

Oberholster PJ, Botha A, Cloete TE. 2006. Use of molecular markers as indicators for winter zooplankton grazing on toxic benthic cyanobacteria colonies in an urban Colorado lake. Harmful Algae 5:705-716.

Ouahid Y, Pérez-Silva G, Del Campo FF. 2005. Identification of potentially toxic environmental Microcystis by individual and multiple PCR amplification of specific microcystin synthetase gene regions. Environ Toxicol 20:235-242.

Ouellette AJ, Handy SM, Wilhelm SW. 2006. Toxic Microcystis is widespread in Lake Erie: PCR detection of toxin genes and molecular characterization of associated cyanobacterial communities. Microb Ecol 51:154-165.

Pan H, Song L, Liu Y, Börner T. 2002. Detection of hepatotoxic Microcystis strains by PCR with intact cells from both culture and environmental samples. Arch Microbiol 178:421-427.

Rantala A, Rajaniemi-Wacklin P, Lyra C, Lepisto L, Rantala J, Mankiewicz-Boczek J, Sivonen K. 2006. Detection of microcystin-producing cyanobacteria in Finnish lakes with genus-specific microcystin synthetase gene E $(m c y E)$ PCR and associations with environmental factors. Appl Environ Microbiol 72:6101-6110.

Ravenschlag K, Sahm K, Pernthaler J, Amann R. 1999. High bacterial diversity in permanently cold marine sediments. Appl Environ Microbiol 65:3982-3989.

Regulation MS N. 518/2004. 2004.Guidelines for Drinking Water Quality, Official Law Report's, March 26, 2004, Section I. p 266.

Roger SO, Bendich AJ. 1985. Extraction of DNA from milligram amounts of fresh herbarium and mummified plant tissues. Plant Mol Biol 5:69-76.

Rozen S, Skaletsky HJ. 2000. Primer3 on the WWW for general users and for biologist programmers. In: Krawetz S, Misener S, 
editors. Bioinformatics Methods and Protocols: Methods in Molecular Biology. Totowa: Humana Press. pp 365-386.

Ruangyuttikarn R, Ivan M, Jeeraporn P, Yuwadee P, Zdenek D. 2004. Reversed phase liquid chromatographic-mass spectroscopic determination of microcystin-LR in cyanobacteria blooms under alkaline conditions. J Chromatogr B 800:315-319.

Saker ML, Vale M, Kramer D, Vasconcelos VM. 2007. Molecular techniques for the early warning of toxic cyanobacteria blooms in freshwater lakes and rivers. Appl Microbiol Biotechn 75:441-449.

Souza RCR, Carvalho MC, Truzzi AC. 1998. Cylindrospermopsis raciborskii (Wolosz.) Seenaya and Subba Raju (Cyanophyceae) dominance and a contribution to the knowledge of Rio Pequeno arm, Billings Reservoir, Brazil. Environ Toxicol Water Qual 13:73-81.

Tillett D, Dittmann E, Erhard M, von Döhren H, Börner T, Neilan BA. 2000. Structural organization of microcystin biosynthesis in Microcystis aeruginosa PCC7806: An integrated peptidepolyketide synthetase system. Chem Biol 7:753-764.
Tooming-Klunderud A, Mikalsen B, Kristensen K, Jakobsen KS. 2008. The mosaic structure of the mcyABC operon in Microcystis. Microbiology 154:1886-1899.

Tsai Y, Olson BH. 1992. Rapid method for separation of bacterial DNA from humic substances in sediments for polymerase chain reaction. Appl Environ Microbiol 58:2292-2295.

Utkilen H, Gjølme N. 1992. Toxin production by Microcystis aeruginosa as a function of light in continuous cultures and its ecological significance. Appl Environ Microbiol 58:1321-1325.

Via-Ordorika L, Fastner J, Kurmayer R, Hisbergues M, Dittmann E, Komárek J, Erhard M, Ingrid C. 2004. Distribution of microcystin-producing and non-microcystin-producing Microcystis $s p$. in European freshwater bodies: Detection of microcystins and microcystins genes in individual colonies. Syst Appl Microbiol 27:592-602.

Watanabe MF, Oishi S. 1985. Effects of environmental factors on toxicity of a cyanobacterium (Microcystis aeruginosa) under culture conditions. Appl Environ Microbiol 49:1342-1344. 